20. Buschman T. Top-down versus bottomupcontrol of attention in the prefrontal and posterior parietal cortices / T. Buschman, E. Miller // Science. - 2007. - 315. - P. 1860-1862.

21. Edelman G. M. The remembered present. A biological theory of consciousness / G. M. Edelman. - New York : Basics Books, 1989. - 346 p.

22. Klimesch W. EEG alpha and theta oscillations reflect cognitive and memory performance: a rewiew and analysis / W. Klimesch // Brain Res. Brain Res. Rev. - 1999. - V. 29 (2-3). - P. 169-195.

23. Knyazev G. G. Motivation, emotion and their inhibitory control mirrored in brain oscillations / G. G. Knyazev // Neurosci. iobehav. Rev. - 2007. - 31 (3). - P. 377-395.

24. Lubar J. F. Neocortical dynamics: implications for understanding the role of neurofeedback and related techniques for the enhancement of attention / J. F. Lubar // Applied Psychophysiology and Biofeedback. 1997. - V2. - P. 111-126.

Юхименко Лилия. Спектрально-когерентные характеристики электроэнцефалограммы у лиц с разной скоростью обработки информации высшими отделами центральной нервной системы. Изучали особенности электрической активности головного мозга (ЭЭГ) и скорость центральной обработки информации (ЦОИ). Установлены статистически значимые отличия мощности и когерентности (Ког) ЭЭГ в группах обследованных с разной ЦОИ. Лица с высокой ЦОИ характеризовались более высокой мощностью и Ког в заинтересованных зонах коры мозга относительно обследованных со средним и низким ее уровнями. Корреляционный анализ подтвердил достоверность связей между характеристиками ЦОИ и ЭЭГ. Выявлены отличия во внутри- и межполушарной спектрально-когерентной динамике характеристик ЭЭГ во время переработки и дифференцирования раздражителей у обследованных в зависимости от ЦОИ. Считаем, что изменение уровня и структуры спектрально-когерентных взаимосвязей потенциалов $\theta, \alpha$ - и $\beta$-диапазонов ЭЭГ может быть нейрофизиологическим коррелятом скорости обработки информации высшими отделами центральной нервной системы.

Ключевые слова: электроэнцефалография, скорость центральной обработки информации, мощность и когерентность ЭЭГ.

Yukhimenko Lilia. Spectral and Coherent Characteristics of Electroencephalogram in Persons with Different Speed of Information Processing by Higher Parts of Central Nervous System. The features of electrical activity of the brain (EEG) and the speed of central information processing (CIP) were studied. Statistically significant differences of capacity and coherence (Coh) of EEG were found in the groups of the examined persons with different CIP. The persons with high CIP were characterized with higher capacity and Coh in the concerned areas of the cerebral cortex if compared with the persons with its middle and low levels. Correlation analysis confirmed the accuracy of the links between the characteristics of CIP and EEG. The differences in intra- and inter-hemispheric spectral-coherent dynamics of EEG characteristics were found during processing and differentiating stimuli in the examined persons depending on the PIC. We consider that the changes in the level and structure of the spectral-coherent linkages of $\theta, \alpha$ and $\beta$-range potentials of EEG can be neurophysiologic correlates of information processing speed by higher parts of the central nervous system.

Key words: electroencephalography, central information processing speed, EEG capacity and coherence.

Стаття надійшла до редколегії 19.09.2016 p.

УДК 599.323.4; 577.115.7; 620.3; 661.846

$$
\begin{aligned}
& \text { Олена Шатинська, } \\
& \text { Руслана Іскра, } \\
& \text { Андрій Пилипець, } \\
& \text { Оксана Сварчевська }
\end{aligned}
$$

\title{
Вплив магній цитрату на вміст ліпідів у плазмі крові щурів за умов експериментального цукрового діабету
}

Досліджено вплив різних доз магній цитрату (100, 250 і 500 мг $\mathrm{Mg}^{2+} /$ кг маси тіла) на вміст ліпідів у плазмі крові щурів з алоксан-індукованим цукровим діабетом. Установлено, що в плазмі крові щурів з експериментальним діабетом підвищувався вміст загальних ліпідів, що супроводжувалося змінами в класах ліпідів плазми крові. Проте з'ясовано, що магній цитрат, який протягом чотирьох тижнів разом із питною водою додавався до раціону тварин, зумовлював стабілізацію досліджуваних показників із наближенням їх до рівня в контрольній групі.

Ключові слова: магній, цукровий діабет, ліпіди, кров.

(C) Шатинська О., Іскра Р., Пилипецьь А., Сварчевська О., 2016 
Постановка наукової проблеми та ії̈ значення. Цукровий діабет у людей і тварин характеризується ендокринними та метаболічними змінами, зокрема абсолютною або відносною недостатністю інсуліну, що призводить до глибоких змін у метаболізмі вуглеводів, білків і ліпідів. Гіперглікемія, а також резистентність до інсуліну можуть призводити до кількісних і якісних порушень у ліпідному складі крові. Ці зміни, зазвичай, супроводжуються підвищенням умісту триацилгліцеролів і холестеролу [11]. Крім того, гіперглікемія зумовлює підвищену екскрецію магнію з організму, який потрібний для нормального протікання багатьох біохімічних реакцій і фізіологічних процесів, що забезпечують енергетику й функції різних органів [9; $10 ; 12]$.

Магній - один із найважливіших біоелементів, що має особливе значення для підтримки метаболічних функцій організму та профілактики ожиріння, гіперінсулінемії й інсулінової резистентності [4; 5]. Фізіологічна роль магнію зумовлена тим, що він $\epsilon$ есенціальним кофактором понад 40 ензимів (гексокіназ, глюкокіназ, фосфофруктомутаз, енолаз), необхідних для обміну вуглеводів, і більше 30 магній-залежних ензимів ліпідного метаболізму (ацил-КоА синтетази середньоланцюгових жирних кислот, лецитин-холестерол ацилтрансферази, лігаз довголанцюгових жирних кислот), задіяних у сигнальному шляху рецептора інсуліну й метаболізмі жирів [4] та передачі енергії від високоенергетичних фосфатних зв'язків [8]. На фоні дефіциту магнію активність цих ензимів різко знижується, що сприяє розвитку різних патологій.

Мета наших досліджень - з' ясувати вплив різних кількостей магній цитрату на ліпідний обмін у крові щурів за умов гіперглікемії.

Матеріали й методи. Дослідження проводили у віварії Інституту біології тварин НААН на білих щурах лінії Вістар масою 130-150 г. Тварин розділено на п’ять груп: КГ - контрольна група; ДГ1 - тварини 3 експериментальним цукровим діабетом (ЕЩД), які споживали питну воду без додавання магній цитрату; ДГ2 - тварини з ЕЦД, яким до питної води додавали магній-цитрат у дозі 100 мг $\mathrm{Mg}^{2+} /$ кг маси тіла; ДГ3 - тварини з ЕЦД, яким до питної води додавали магній-цитрат у дозі 250 мг $\mathrm{Mg}^{2+} /$ кг маси тіла; ДГ4 - тварини з ЕЩД, яким до питної води додавали магній-цитрат у дозі $500 \mathrm{мг} \mathrm{\textrm {Mg } ^ { 2 + } / \kappa г ~ м а с и ~ т і л а . ~ Т в а р и н а м ~ у с і х ~ г р у п ~ з г о д о в у в а л и ~ с т а н д а р т н и и ̆ ~ к о м б і к о р м ~ д л я ~ л а б о р а т о р н и х ~}$ щурів. Через місяць від початку експерименту з метою індукції ЕЦД тваринам усіх дослідних груп на тлі 24-годинного голодування одноразово внутрішньоочеревно вводили розчин алоксан моногідрату з розрахунку 150 мг/кг маси тіла [15; 16]. Для підтвердження гіперглікемії проводилося щотижневе вимірювання глюкози крові, зібраної з хвостової вени, за допомогою портативного глюкометра («Gamma Mini»).

Утримання тварин та експерименти проводили відповідно до положень «Свропейської конвенції про захист хребетних тварин, які використовуються для експериментів й інших наукових цілей» (Страсбург, 1985), Загальних етичних принципів експериментів на тваринах, ухвалених Першим національним конгресом із біоетики (Київ, 2001).

Після закінчення досліджень тварин декапітували за допомогою легкої анестезії ефіром. Матеріалом для досліджень слугувала плазма крові. Ліпіди плазмі крові (1мл) екстрагували сумішшю хлороформметанол (2:1) за методом Фолча й визначали їх кількість ваговим методом [13]. Розділення ліпідів на класи проводили методом тонкошарової хроматографії на силікагелі в системі розчинників гександіетиловий ефір-льодяна оцтова кислота (70: 30 : 1), кількість ліпідів визначали біхроматним методом [2].

Одержані цифрові дані обробляли статистично за допомогою комп'ютерної програми «Statistika». Для визначення вірогідних відмінностей між середніми величинами використовували критерій Стьюдента.

Виклад основного матеріалу та обгрунтування отриманих результатів дослідження. У ході проведених досліджень у плазмі крові щурів виявлено зміни вмісту класів ліпідів, зокрема фосфоліпідів, холестеролу, диацилгліцеролів, триацилгліцеролів, вільних (неетерифікованих) жирних кислот та етерифікованого холестеролу.

Також виявлено тенденцію до зростання вмісту загальних ліпідів у тварин ДГ1 з ЕЦД на 8,71 \% відносно тварин контрольної групи. Відомо, що саме ліпіди - основне джерело енергії для організму за цукрового діабету, тому закономірною є підвищена мобілізація ліпідів із їхнього депо i, як наслідок - зростання вмісту ліпідів у крові (гіперліпопротеїнемія) [3]. Водночас за умови додавання до раціону магній-цитрату у тварин ДГ2 і ДГ4 виявлено зниження вмісту загальних ліпідів на 2,20 i 8,22\% відповідно, порівняно 3 тваринами ДГ1. Це може бути зумовлено тим, що достатній уміст магнію в організмі забезпечує підтримання активності ензимів ліпідного обміну [4]. Натомість у плазмі крові тварин ДГЗ виявлено зростання вмісту загальних ліпідів на 6,97 \% відносно тварин ДГ1 (рис. 1). 


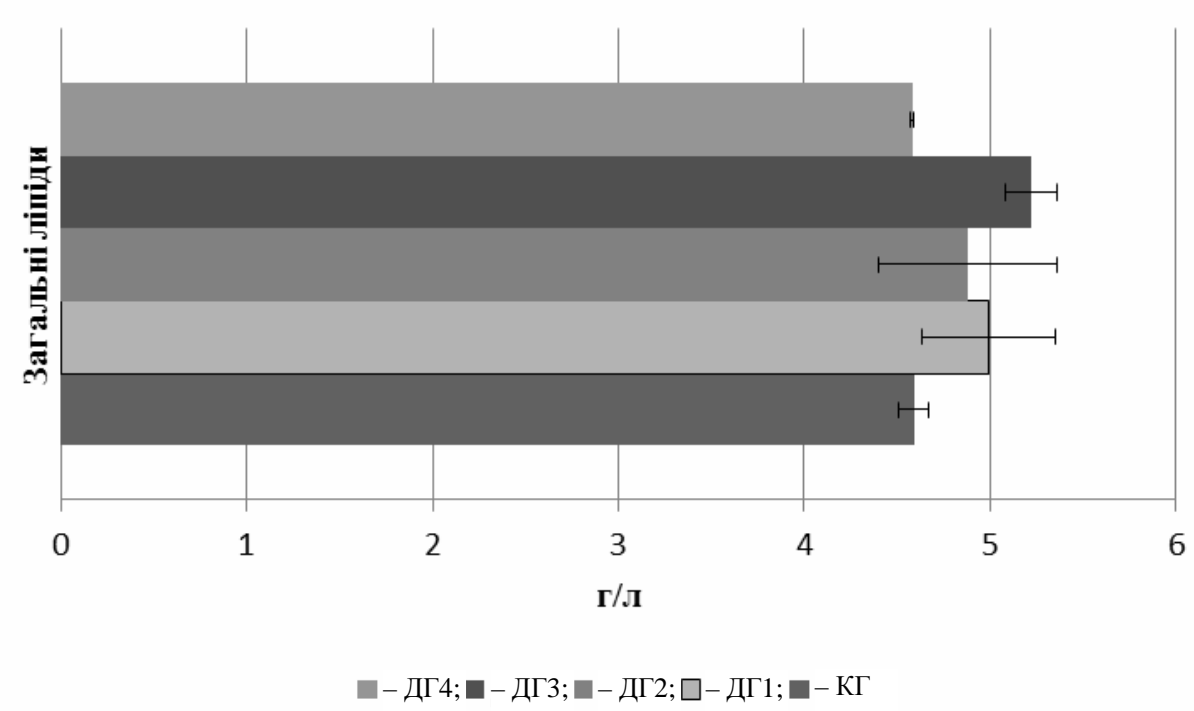

Рис. 1. Уміст загальних ліпідів у плазмі крові щурів, г/л

У плазмі крові щурів з ЕЦД виявлено суттєве збільшення вмісту холестеролу, триацилгліцеролів - на 4,89 \%, фосфоліпідів - на 5,68 \%, ефірів холестеролу - на 11,88 \% і вільних жирних кислот - на 3,59 \% та суттєве зниження вмісту диацилгліцеролів, порівняно з їх умістом у плазмі крові тварин контрольної групи (рис. 2). Висока концентрація ліпідів у плазмі крові, особливо холестеролу, переважно є результатом збільшення мобілізації жирних кислот із периферичних тканин і посилення ліполізу на фоні нестачі інсуліну [14].

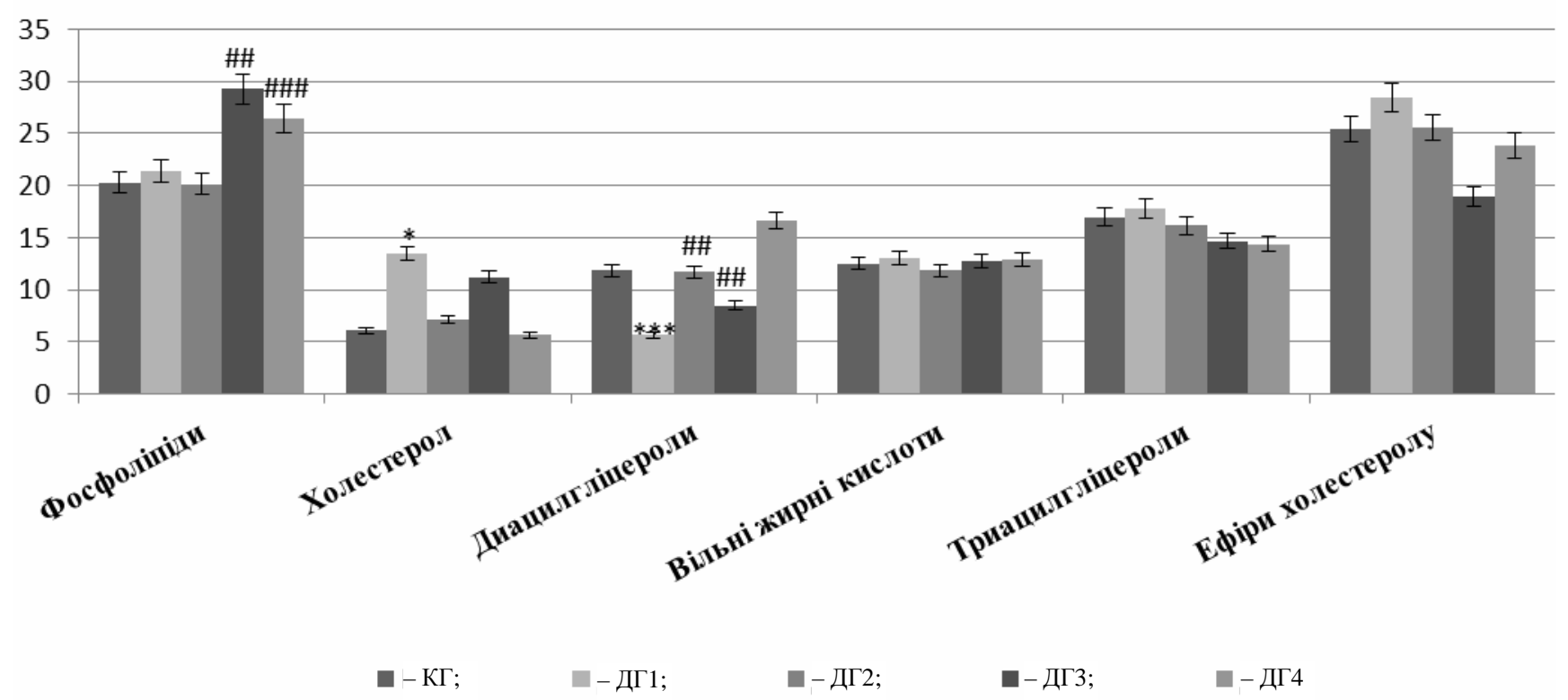

Рис. 2. Уміст класів ліпідів у плазмі крові щурів, \%

Примітка. * - p<0,05; *** - p<0,001 - вірогідність відносно тварин КГ; ${ }^{\#}-p<0,01 ;{ }^{\# \#}-p<0,001$ - вірогідність відносно тварин ДГІ.

У плазмі крові щурів ДГ2 виявлено достовірне суттєве збільшення вмісту диацилгліцеролів та зменшення вмісту фосфоліпідів на 5,93 \%, холестеролу - на 48,08 \%, триацилгліцеролів - на 9,32 \%, вільних жирних кислот - на 8,78 \% й ефірів холестеролу - на 10,06\%, порівняно з їх умістом у плазмі крові тварин ДГ1 з ЕЦД. 
При дослідженні ліпідів плазми крові щурів ДГз виявлено зниження вмісту холестеролу на $17,04 \%$, вільних жирних кислот - на 1,85\%, триацилгліцеролів - на 17,57 \% та ефірів холестеролу на $33,47 \%$, порівняно з ї умістом у плазмі крові тварин ДГ1. Водночас простежено достовірне підвищення вмісту фосфоліпідів на 36,57 \% і диацилгліцеролів на 50,27 \%, порівняно 3 тваринами ДГ1 з ЕЦД.

У плазмі крові щурів ДГ4 виявлено достовірне зростання вмісту фосфоліпідів на 23,45 \% і суттєве зростання вмісту диацилгліцеролів, а також зменшення вмісту холестеролу на $57,81 \%$, вільних жирних кислот - на 0,15\% і триацилгліцеролів - на 19,09 \% та ефірів холестеролу - на 16,1 4 \%, порівняно з їх умістом у плазмі крові тварин ДГ1 з ЕЦД.

Нормалізація показників ліпідного спектра плазми крові може бути зумовлена впливом магній цитрату на ліпідний обмін через дію інсуліну. Оскільки дефіцит магнію в організмі негативно впливає на секрецію й активність інсуліну, що сприяє формуванню та прогресуванню інсулінорезистентності (IP), а обидва чинники (IP і нестача магнію) впливають на утилізацію жирів, сприяючи розвитку діабетичної дисліпідемії [7].

Зниження концентрацій холестеролу в плазмі крові за дії магній цитрату може бути викликане включенням його в процес відновлення біологічних мембран, що в умовах окиснювального стресу й посилення пероксидного окиснення ліпідів за діабету піддаються значним ушкодженням [1].

Збільшення вмісту фосфоліпідів у плазмі крові тварин ДГЗ і ДГ4, можливо, пов'язане зі зменшенням активації їх гідролізу за дії магнію.

Відомо, що в'язкість біологічних мембран залежить від багатьох факторів, але передусім від фракційного складу фосфоліпідів і вмісту холестеролу. Отримані дані свідчать про те, що в крові тварин з ЕЦД суттєво зростає співвідношення холестерол / фосфоліпіди, порівняно з тваринами КГ. Проте за додавання до раціону тварин магній-цитрату простежено зменшення співвідношення холестерол / фосфоліпіди на 44,44 \% у тварини ДГ2, 39,68 \% - ДГ3 і 65,08 \% - ДГ4, що свідчить про зниження жорсткості мембран (рис. 3). Такі зміни нормалізують активність мембранозв'язаних ензимів і роботу транспортних систем [6].

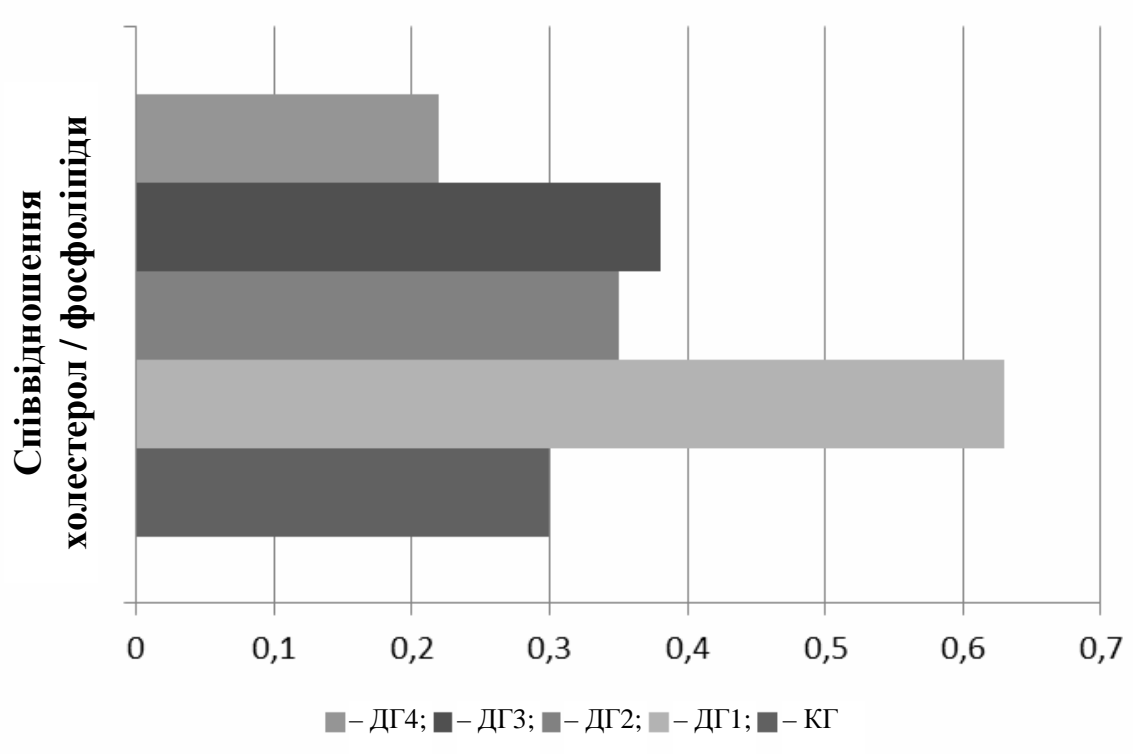

Рис. 3. Співвідношення холестерол / фосфоліпіди

Висновки та перспективи подальшого дослідження. Нашими дослідженнями з'ясовано, що нормалізація рівня ліпідного обміну в крові щурів із діабетом до рівня тварин контрольної групи

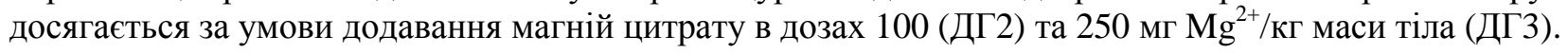

\section{Джерела та література}

1. Данилова А. О. Вплив високовуглеводних препаратів з пробіотичними мікроорганізмами на стан щурів 3 алоксановим діабетом / А. О. Данилова // Досягнення біології та медицини. - 2012. 
2. Лабораторні методи дослідження у біології, тваринництві та ветеринарній медицині : довідник / В. В. Влізло, Р. С. Федорук, І. Б. ратич та ін. ; за ред. В. В. Влізла. - Львів : СПОЛОМ, 2012. - 764 с.

3. Кузишин О. В. Біохемія цукрового діабету. - 1 : Теоретична частина (огляд) / О. В. Кузишин, Н. В. Ковалишин; Х. В. Алмашина // Вісник Прикарпатського національного університету імені Василя Стефаника. - Серія «Хімія». - 2010. - Вип. IX. - С. 74-115.

4. Громова О. А. Роль магния в формировании метаболического синдрома, коррекции избыточной массы тела и ожирения у детей и подростков / О. А. Громова, Л. Э. Федотова, Т. Р. Гришина [и др.] // Педиатрия. 2014. - T. 93, №2. - С. 123-133.

5. Корпачев В. В. Метаболические эффекты и клиническое применение магния оротата / В. В. Корпачев, Н. М. Гурина // Международный эндокринологический журнал. - 2007. - Вип. 2, № 8. - С. 4-11.

6. Чекман И. С. Фармакология / И. С. Чекман, Н. А. Горчакова, П. А. Галенко-Ярошевский. - Киев : ООО «Рада», 2003. - С. 816.

7. Шилов А. М. Роль дефицита магния в сердечно-сосудистом континууме / Шилов А. М. // Лечебное дело. - 2013. - Вип. 4. - С. 73-82.

8. Юлиш Е. И. Роль магния в норме и патологи / Е. И. Юлиш // Журнал «Здоровье ребенка». - 2007. Вип. 5, № 8. - С. 49-52.

9. Barbagallo M. Magnesium and type 2 diabetes / M. Barbagallo, L. J. Dominguez // World journal of diabetes. 2015. - Vol. 6, № 10. - P. 1152-1157.

10. Barbagallo M. Magnesium metabolism in type 2 diabetes mellitus, metabolic syndrome and insulin resistance / M. Barbagallo, L. J. Dominguez // Archives of biochemistry and biophysics. - 2007. - Vol. 458, №1. P. 40-47.

11. Georg, P. Lipids and diabetes / P. Georg, B. Ludvik // Journal of clinical and basic cardiology. - 2000. - Vol. 3, №3. P. 159-162.

12. Giacco F. Oxidative stress and diabetic complications / F. Giacco, M. Brownlee // Circulation research. 2010. - Vol. 107, № 9. - P.1058-1070.

13. Kates M. Techniques of lipidology / M. Kates. - Amsterdam : Elsevier, 1986. - P. 451.

14. Sankaran, M. Modulation of antioxidant status, carbohydrate and lipid metabolism by melatonin on streptozotocin induced diabetic rats / M. Sankaran, P. Jayakumar, T. Gomathy // Journal of Biochemical Technology. 2013. - Vol. 4, № 1. - P. 524-530.

15. Sharma Sh. Experimental models of diabetes / Sharad Sharma, Jaya Dwivedi, Jha A.K. [et al.] // Intern. J. Res. Ayur.Pharm. - 2010. - Vol. 1, №2. - P. 292-301.

16. Von Herrath M. Animal models of human type 1 diabetes / M. Von Herrath, G. T. Nepom // Nature Immunol. - 2009. - Vol. 10.- №. 2. - P. 129-132.

Шатинская Елена, Искра Руслана, Пилипец Андрей, Сварчевская Оксана. Влияние цитрата магния на содержание липидов в плазме крови крыс при условиях експериментального сахарного диабета. Исследовали влияние различных доз цитрата магния $\left(100,250\right.$ и 500 мг $\mathrm{Mg}^{2+} / \kappa г$ массы тела) на содержание липидов в плазме крови крыс с аллоксаном-индуцированным сахарным диабетом. Установлено, что в плазме крови крыс с экспериментальным диабетом повышалось содержание общих липидов, что сопровождалось изменениями в классах липидов плазмы крови. Однако установлено, что цитрат магния, который в течение четырех недель вместе с питьевой водой добавлялся в рацион животных, предопределял стабилизацию исследуемых показателей с приближением их к уровню в контрольной группе.

Ключевые слова: магний, сахарный диабет, липиды, кровь.

Shatynska Olena, Iskra Ryslana, Pylypets Andrii, Svarchevska O. The Influence of Magnesium Citrate on the Plasma Lipids Content of Rats Under Condition of Experimental Diabetes Mellitus. The influence of the different doses of magnesium citrate $\left(100,250\right.$ and $500 \mathrm{mg} \mathrm{Mg}^{2+} / \mathrm{kg} \mathrm{b.w.)} \mathrm{on} \mathrm{the} \mathrm{plasma} \mathrm{lipids} \mathrm{content} \mathrm{of} \mathrm{rats} \mathrm{with} \mathrm{alloxan-}$ induced diabetes was investigated. It was found the increasing of the content of general lipids in plasma of rats with experimental diabetes. This stage was accompanied by changes in the classes of plasma lipids. However, magnesium citrate, which had been added for four weeks with drinking water to the rats diet, allows stabilize studied parameters, approaching them to normal.

Key words: magnesium, diabetes, lipids, blood.

Стаття надійшла до редколегії 11.09.2016 р. 